Article

\title{
Coping with and Adapting to Climate Change: A Gender Perspective from Smallholder Farming in Ghana
}

\author{
Elsie Assan ${ }^{1, *(1)}$, Murari Suvedi ${ }^{1}$, Laura Schmitt Olabisi ${ }^{1}$ and Andrea Allen ${ }^{2}$ \\ 1 Department of Community Sustainability, Michigan State University, Room 135, 480 Wilson Road, \\ East Lansing, MI 48824, USA; suvedi@msu.edu (M.S.); schmi420@msu.edu (L.S.O.) \\ 2 Center for Advanced Study of International Development, College of Social Science, \\ Michigan State University, 427 N. Shaw Lane, Room 202, East Lansing, MI 48824, USA; allenan9@msu.edu \\ * Correspondence: assanels@msu.edu
}

Received: 23 June 2018; Accepted: 21 July 2018; Published: 25 July 2018

\begin{abstract}
The negative impacts of climate change on agriculture could erode gains made toward gender equality in Ghana. Much of the literature on gender dimensions of climate change adaptation has focused on assessing differences in coping and adaptation practices of smallholder farmers. Mostly overlooked is whether gender influences influenced perception of effectiveness of adaptation practices and preferences for institutional support for future adaptation. Using key informant interviews, household surveys, and focus group discussions, we address these gaps by exploring coping and adaptation measures adopted by heads of farm households to counter climate change impacts on their livelihood activities and household well-being in the Guinea Savanna agroecological zone in Ghana. Additionally, we assessed the preferred institutional adaptation support of heads of farm households in adapting to future projected impacts. We find that female heads of farm households relied mainly on borrowed money from village savings and loans group as a coping measure; male heads of farm households depended primarily on sales of livestock. Varying planting and harvesting dates, crop diversification, and use of improved crop varieties were the major adaptation strategies adopted by farmers. We argue that provision of dams and/or dugouts, postharvest processing facilities, adaptation capacity-building resources, and improved access to markets and credit could enhance the adaptive capacity of male and female heads of farm households to mitigate projected climate change impacts on their livelihood activities and household well-being.
\end{abstract}

Keywords: gender; climate change adaptation; agriculture; food security

\section{Introduction}

Agriculture remains an important part of the economies of countries in West Africa, contributing to national gross domestic product (GDP), foreign exchange earnings, and food security. Despite these contributions, the sector is inundated with many challenges. Paramount among these are climate change-related factors such as irregular rainfall patterns, increasing temperature and incidence of droughts, and decreasing soil fertility [1]. Climate change projections of rainfall variations and increased incidence of extreme climatic events could negatively impact agriculture and affect the gains made toward food security and rural development because food production activities depend largely on rainfall [2].

Agriculture remains the backbone of Ghana's economy, with more than $50 \%$ of the active labor force engaged in the sector and supplying most of the national food requirements for the population [3]. Climate change projections across the country point to increasing temperatures across all ecological zones, with temperatures during the dry season expected to increase by about $3{ }^{\circ} \mathrm{C}$ 
by 2080. Projected changes in precipitation during the wet season are crowded with uncertainty [4]. In northern Ghana, climate change models show decreasing trends in rainfall, increases in temperature, and increasing incidence of late onset of spring rains [4,5]. These projected changes in rainfall and temperature could adversely affect agricultural production in the region, given that the region has only one rainy season, and agricultural production depends excessively on rainfall. The probable effects of climate change on agriculture could include yield losses, loss of farm income, and reduced well-being of farm households $[1,6]$. These adverse impacts of climate change could also stifle efforts toward poverty reduction among rural dwellers, who depend on agriculture and other climate-sensitive activities for their livelihoods and well-being. Others studies have shown that an annual average of $5.5 \%$ of total output of the major staples-maize, rice, cassava, yams, millet, sorghum, groundnuts, and plantain-is lost to climatic, biological, and natural disasters in Ghana [7]. Also, Nyuor et al. [8] found that increased temperature negatively affects revenues generated from crop production by farmers in northern Ghana. Thus, it is crucial for farmers to undertake adaptation strategies to help cushion them against the adverse impacts of climate change. Additionally, state agencies and other stakeholders of agriculture must undertake adaptation measures and implement policies focused on transforming the agricultural sector to enhance resilience of farm households.

Farmers have been adapting to variability in precipitation and average temperature over several decades [9-12]. In northeastern Ghana, Bawakyillenuo et al. [10] found that farmers engaged in crop and livestock diversification, intensification of irrigation, and diversification into nonfarm income-generating activities to improve their livelihoods. However, very little is known about the gendered nature of these adaptation practices at the farm household level in Northern Ghana. Farmers' ability to adapt to projected trends in rainfall and temperature partly depends on institutional support for adaptation. The institutional support must be gender-sensitive and designed to accommodate farmers' preferences $[4,13]$. Incorporating farmers' views into adaptation planning is important because literature suggests that the adverse impacts of climate change on agriculture will be felt unequally within the country [14]. Climate change impacts are expected to differ across agroecological zones and among households because of differences in resources, which tend to influence adaptive capacity [15]. Gender mainstreaming in climate change adaptation intervention planning is crucial, given the gendered nature of climate change vulnerabilities [16,17]. Like males, females also have agency and important knowledge that is useful in climate adaptation intervention planning, and development of strategies for tackling climate change impacts related to food security and household well-being [16].

Studies have been conducted in Ghana to explore the linkages between gender and climate change adaptation in agriculture. These have focused on the gender dimensions of climate change vulnerabilities [18], the adaptation strategies adopted by farm households [15,19] to counter the adverse impacts of climate change, and the importance of adaptation strategies [5]. Mostly overlooked is whether gender influences the perceived effectiveness of adaptation practices, preferences for institutional support for adaptation, and the sources of these institutional supports. There is discussion on the need for provision of gender-sensitive institutional support to improve farmers' resilience to current variability in precipitation and temperature and to enable the farmers to effectively adapt to future climatic changes. The success of such intervention partly depends on understanding the gender perspectives of farm households on the effectiveness of current adaptation measures and preferences for institutional adaptation support. The knowledge of these gender differences could help in the development of gender-sensitive policy and adaptation practices to build farmers' resilience to adverse climate change impacts.

Using qualitative data from key informant interviews and focus group discussions and quantitative data from cross-sectional surveys of farm households in three communities in the Lawra district of Ghana, this study explored the coping and adaptation measures adopted by male and female heads of farm households to counter climate change impacts. The study also explored the perspectives of farmers on the effectiveness of current adaptation practices in contributing to reduced 
vulnerability to adverse impact of climate. Additionally, their preferred institutional support for adapting to future changes in rainfall and temperature, and the preferred sources for the adaptation support were assessed. This study aims to broaden understanding of gender perspectives on climate change adaptation and inform the development of adaptation strategies tailored to the preferences of farm households.

This paper is organized into seven sections. The section following the introduction gives an overview of the literature on farmers' climate change adaptation and coping practices in mitigating adverse climate change impacts. This is followed by a conceptual framework that discusses the importance of gender analysis in climate change adaptation. The methods section comprises a brief description of the study area, data collection and analysis processes. Following the methods section are the results (presented under seven thematic areas) and discussion. The concluding section provides a summary of the significant findings of the study and discusses the implications of those findings for integrating gender perspectives in climate change policy and adaptation planning.

\section{Climate Change Adaptation in Agriculture with a Focus on Ghana}

Many smallholder farmers in sub-Saharan Africa adjust their farm management practices to variations in the local climate and other factors such as unavailable markets, high input costs, and lack of infrastructure, to secure their livelihoods [20]. The projected impacts of climate change on agriculture require that farmers undertake coping and adaptation strategies to minimize their vulnerability to the impacts [4,21]. Coping strategies are defined as short-term measures undertaken by farmers to deal with food or income shortages in abnormal cropping seasons or years [22]. Farmers employ coping measures in an effort to minimize risk and vulnerability to food insecurity and loss of income due to threats from climatic and non-climatic stressors [22]. Adaptation is "adjustments in natural or human systems in response to actual or expected climatic stimuli or their effects, which moderate harm or exploit beneficial opportunities" [23] (p. 6). Adaptation to negative impacts of climate change is imperative because failure to adapt could lead to dire consequences such as loss of livelihood, social conflicts and displacement, and even death [24]. Adaptation measures are meant to reduce vulnerabilities of individuals to adverse impacts of climate change while ensuring sustainability. Effective adaptation among farmers requires changes in processes, practices, and structures to achieve sustainable development [25].

Nhemachena and Hassan grouped farm-level adaptations into two categories: increased crop diversification, which involves the cultivation of species or cultivars that are tolerant to weather variations, and changes in farm management practices that ensure that critical crop growth stages do not coincide with unfavorable weather conditions [26]. Crop diversification in agriculture has the potential to protect farm businesses from total crop failure because various crops respond differently to rainfall variations and related climatic events, and changes in farm management practices may reduce yield losses [27]. Increased use of irrigation, increased use of water and soil moisture conservation techniques, and diversification to non-farm activities have also been employed as adaptation measures $[9,28]$.

Bawakyillenuo et al. found that farmers adopted changes in tillage practices and intensification of irrigation to counter the adverse effects of variability of rainfall and temperature on their production activities in northeastern Ghana [10]. Fosu-Mensah et al. found that farmers in southern Ghana engaged in diversification of income generation activities during the dry season and varied their planting and harvesting dates with the goal of reducing the negative impacts of climate change [29]. Absent in the scholarly discourse are farmers' perspectives on the effectiveness of the identified adaptation measures in mitigating climate change impacts.

Adaptation, to a large extent, depends on the farmers' adaptive ability to counter the impacts and risks of climate change. This adaptive ability is influenced by their socioeconomic characteristics [25]. Some researchers have argued for institutional support to enable farmers to adapt to current and future variations in climate and to improve their resilience $[4,6]$. According to Rosenthal and Kurukulasuriya, 
the support could be provided by government agencies, nongovernmental organizations, and other stakeholders in agriculture [6]. Examples of such support include providing community irrigation systems, resourcing research institutions to develop climate-tolerant crop varieties, providing agricultural insurance, building capacity of farmers, creating opportunities for stable income, and providing credit and extension services [6,11,29].

Incorporating grass-roots perspectives and accounting for gender perspectives in planning institutional support for farmers are critical because men and women farmers may face different constraints to adaptation and prefer different types of adaptation support because of differences in adaptive capacities and roles $[13,15,30]$. Codjoe et al. in their study demonstrated that men and women farmers differed in their preferences of support for adaptation [5]. For example, female farmers preferred wells and boreholes, bushfire control, and water harvesting, while male farmers preferred irrigation, wells, boreholes, and drought-tolerant crop varieties in adapting to drought conditions. Similar observations were made by [13], who assessed adaptation practices among farmers in Uganda and Ghana. Adaptation intervention preferences among farmers at the household level, however, are yet to be studied. Thus, this study relies on empirical data from northwestern Ghana to assess the adaptation intervention preferences of male and female heads of farm households to mitigate climate change impacts.

\section{Conceptual Framework: Gender Analysis of Climate Change Coping and Adaptation Practices}

This paper draws on gender analysis, a crucial component of the gender and development theory, to examine the climate change coping and adaptation of farm households. As an analytical framework, gender analysis encompasses information on males and females in terms of their roles, responsibilities, access to and control of resources, and opportunities, as well as hidden power structures that govern the relationships between them [31]. It could also include social variables such as ethnicity, social class, and age [19]. Gender constructions in most societies tend to influence the access of males and females to critical resources necessary for their development, leading to gendered vulnerabilities. In the context of climate change adaptation, these gender constructions could affect the abilities of males and females to cope with and adapt to adverse impacts of climate change on their livelihood activities and potentially worsen existing gender inequalities among farm households. Hence, it is crucial to understand the gender dimensions of current coping and adaptation measures adopted by farm households, their perceptions of the effectiveness of these adaptation practices, and their preferences for institutional support for future adaptation to improve adaptation planning and strategies development processes [19,30]. For example, [30] in using gender analysis in climate change adaptation among different farming systems in Mali drew attention to the important role that the inclusion of perspectives of male and female farmers plays in the development of gender-sensitive adaptation and mitigation strategies.

In this paper, "gender" represents the different ways in which male and female heads of farm households cope with and adapt to the adverse effects of climate change on their livelihood activities and the well-being of their households. Male heads of farm households consist of adult males who are single, are cohabiting, or married (and live in the same house with one or more wives), or are widowed, and serve as the main decision makers in the farm households. Similarly, female heads of farm household are adult females who are single or married/cohabiting (with husbands/partners absent for most of the calendar year), or are widowed, and could be the main decision makers of the farm households [32]. Ultimately, we contribute to gender and climate change adaptation scholarship by exploring the different coping and adaptation practices that farm household heads undertake in mitigating adverse climate change effects on their livelihood activities and the well-being of their households. 


\section{Methodology}

\subsection{Study Area}

The study focused on three communities-Mettoh, Kasalgri, and Tabier-in the Lawra district (Figure 1) of the Upper West Region of Ghana. The Lawra district lies within the Guinea Savanna agroecological zone, which is classified as semi-arid and is characterized by two seasons: the dry season (November to April) and the wet season (May to October) [5]. According to the Ghana Statistical Service, about $88 \%$ of the district's population of 54,889 live in rural communities, and about $90 \%$ of the rural households are engaged in agriculture [33]. Most households are into crop farming and livestock rearing. There are slightly more females (52\%) in the district than males (48\%). Vegetation in the district is characterized by short grasses and few woody plants [33].

The nature of the soils, together with frequent droughts, dry spells, and floods, tends to adversely affect crop production with implication for household food security in the district [33]. The main crops produced by farmers are maize, millet, groundnuts, soya bean, and cowpea. The majority of crop production activities are done in the rainy season because agriculture in the district is mostly rain-fed and at the subsistence level [33]. For these reasons and the increasing number of female-headed farm households in the district [19], the district was chosen to explore the objectives of this study.

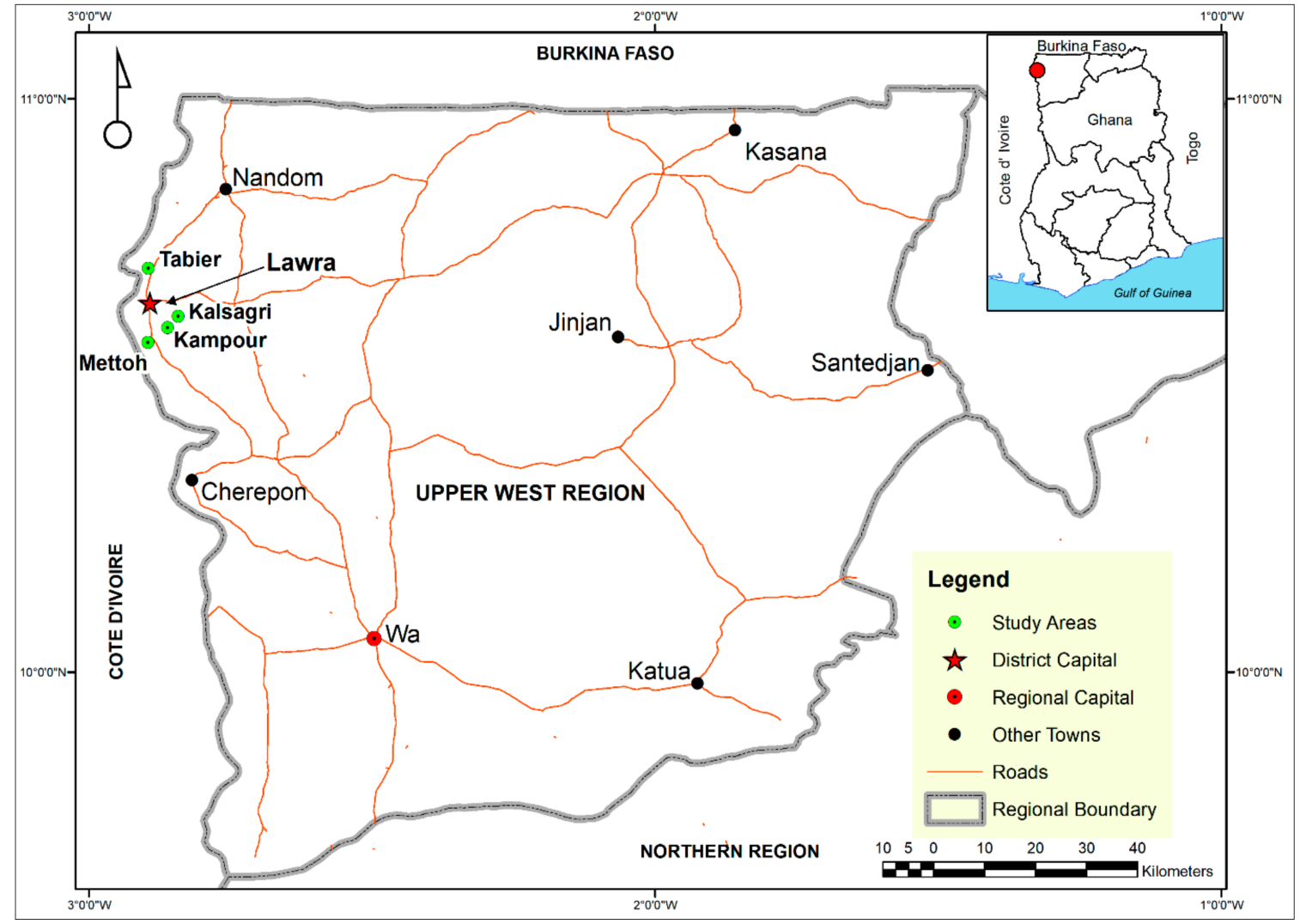

Figure 1. Map of the Study Area.

\subsection{Data Collection and Analysis}

The study was designed to cover male and female heads of farm households from three communities (Mettoh, Kasalgri, and Tabier) in the Lawra district of the Upper West Region of Ghana. The survey was approved by the Michigan State University Institutional Review Board (IRB\# x17-628e). The data collection was carried out in three phases-key informant interviews, a household survey, and focus group discussions. The first phase involved key informant interviews with traditional 
leaders and agricultural workers in the district. Purposive sampling was used to select the participants for the key informant interviews. This sampling procedure was used because it allows the collection of information from participants who are well versed in the phenomenon under investigation [34]. A total of nine key informant interviews were conducted using an interview guide. Two key informant interviews involving a male and a female were conducted in each community; three were with agricultural workers in the district. The key informant interviews explored how agriculture has been affected by changes in climate from 2006 to 2016. It also assessed practices that build households' resilience to climate change and identified institutional interventions to help households to cope and adapt to future climate impacts. The key informant interviews were conducted first with the aim of using information from the process to revise the household survey instrument and explain findings from the household survey where necessary.

The second phase of data collection involved a survey of households in the study communities. The goal of the surveys was to further probe awareness of climate change coping and adaptation practices, and preferred institutional support for adapting to future changes in rainfall and temperature among male and female heads of farm households. The survey instrument was developed on the basis of a literature review on climate change adaptation practices among smallholder farmers. The survey was designed to measure the sociodemographic characteristics of farmers, current climate change coping and adaptation practices, the perceived effectiveness of current adaptation strategies, farmers' preferred institutional supports for future adaptation, and their preferred sources of these supports. The list of adaptation strategies covered those implemented by the farmers to reduce crop losses and to provide an alternative source of income for the households. A mix of open-ended and Likert-type questions was used. The households were selected with the assistance of a community person. The following criteria were used in selecting households to participate in the study: male-headed, with one or more wives; male-headed, divorced, single, or widowed; female-headed, divorced, single, or widowed; female-headed, husband or partner away, husband/partner makes most household and farm decisions; and female-headed, husband/partner away, wife makes most household and farm decisions. Convenience sampling was used in selecting household heads. This sampling procedure was used because at the time of data collection (June 2017), farmers were busy with land preparations and planting activities. A total of 124 farm household heads participated in the study; 68 of these were females. The survey was administered in a face-to-face interview with the help of enumerators drawn from the Lawra office of the Ministry of Food and Agriculture, and Women in Agriculture Development. The enumerators were taken through a two-day training program to acquaint them with relevant skills to administer the survey to participants. Before commencement of the survey, the survey instrument was pretested to ensure suitability of the instrument to the local context. Feedback from the pretesting as well as findings from the key informant interviews were used to fine-tune and finalize the survey instrument.

The final phase of data collection consisted of five focus group discussions. The focus group were conducted in the final stage to address questions that arose during the key informant interviews and household surveys. Two focus groups-one for males only and one for females only-were conducted in both Kasalgri and Mettoh. The fifth focus group was conducted with both males and females from the Tabier community. In each community, invitation was extended to 12 men and 12 women. A total of 54 farmers participated in the focus group discussions-26 males and 28 females (Table 1). The focus group participants were purposively selected with the help of a local person. The criteria for selection were a person's availability and willingness to participate in the process as well as the type of farm household (male- or female-headed) each represented. A focus group discussion guide was used in the data collection process and a translator used to translate the questions and responses from English to the local language and the local language to English, respectively. All the interviews and focus group discussions were audio-recorded with permission from participants and later transcribed for processing and analysis. 
The qualitative data from the interviews and focus group discussions were analyzed following a grounded theory approach [35]. The interview and focus group transcripts were reviewed multiple times to identify dominant themes and concepts. Using open coding [36], the researchers coded the transcripts, drawing on existing literature on gender and climate change adaptation and the study objectives to help extract the salient themes and improve data organization. The resulting themes were compared across the data sources to identify areas of similarities and differences [37]. The quantitative data generated from the household surveys were analyzed using descriptive statistics such as means, standard deviations, crosstabs, frequencies, and percentages using SPSS version 22.

Table 1. Communities and focus group sample size.

\begin{tabular}{cccc}
\hline Community & Number of Males $(\boldsymbol{N}=\mathbf{2 6})$ & Number of Females $(\boldsymbol{N}=\mathbf{2 8})$ & Total $(\boldsymbol{N}=\mathbf{5 4})$ \\
\hline Mettoh & 7 & 8 & 15 \\
Kasalgri & 9 & 12 & 21 \\
Tabier & 10 & 8 & 18 \\
\hline
\end{tabular}

\section{Results}

The findings were analyzed by the gender of the farm household head. The findings were presented under seven overarching themes of coping and adaptation measures adopted by farm household heads to counter climate change impacts and their perceived effectiveness of current adaptation practices. We defined coping measures as activities that farmers engage in to reduce risk and vulnerability to food insecurity and loss of income after encountering climatic and non-climatic shocks. Adaptation measures, on the other hand, were defined as activities (usually at the farm level) that farmers engage in to reduce the effects of climatic stressors on their livelihood activities. We distinguished between the two practices because understanding of these is critical for the selection of alternative livelihood options and farm-level adaptation practices suited to the local context and needs of male and female farmers. In addition, we reported the preferred institutional adaptation supports of male and female heads of farm households required for mitigating climate change impacts.

\subsection{Sociodemographic Characteristics of Study Participants}

Slightly more than half (55\%) of the study participants were female heads of farm households. There were slightly more male heads of farm household with one or more wives $(42 \%)$ than de jure female heads of farm households (32\%) and de facto female heads of farm households (23\%). About $3 \%$ of the male heads of farm households were single, divorced, or widowed. More males than females had had some form of formal education. About $25 \%$ of the male respondents had some form of formal education, with the highest level of education being a university degree ( $2 \%)$. Among female participants, $12 \%$ reported having attained some form of formal education, with the highest level of education being basic education (3\%).

About $69 \%$ of female heads and $46 \%$ male heads of farm households were part of a social group in the community. More male heads of farm households (16\%) had access to formal credit than female heads of farm households (1\%). About $47 \%$ of the female heads of farm households owned their farmland. Other female heads secured their farmland through their fathers, brothers, or husbands, or by renting/sharecropping (53\%). A majority $(96 \%)$ of the male heads of farm households owned their land; the remaining secured their farmlands through sharecropping or allocation from their fathers $(4 \%)$. The findings on land ownership reflect cultural practices in the area, where lands are customarily owned by male heads and passed on to their sons. A woman can assume temporary ownership of farmland with permission from a brother-in-law upon the death of a husband, but she will have to return ownership to the husband's family when she returns to her family, or transfer ownership to her first son when he reaches adulthood. 


\subsection{Gender and Climate Change Coping Measures Adopted by Farm Households}

The coping measures adopted by male and female heads of farm households to deal with low food and income availability (due to impacts of climate change on their livelihood activities) are shown in Figure 2. We found a gendered pattern to the coping measures adopted by households to counter the negative impacts of the climatic stressors. The four topmost activities adopted by female heads of farm household were: borrowing money from friends, relatives, or village savings and loans association (VSLA) (45\%); selling wild fruits and vegetables (29\%); selling firewood and/or processing shea nuts $(19 \%)$; and selling livestock (18\%). The female heads of farm households increasingly engaged in these coping activities during the dry season because of lack of alternative livelihood options and economic opportunities. Another reason for these activities was their inability to raise the needed capital to undertake other livelihood options, such as beekeeping, and pastry and soap making. They had to use the little money obtained from farming or borrowing to support their families. In addition, husbands must give permission to de facto female heads of farm household before they could sell livestock to meet household needs because women in the communities were not considered as owners of the household livestock.

Male heads of farm households sold livestock (45\%), migrated to look for jobs (21\%), borrowed money from friends, relatives and/or village savings and loans association (VSLA) (21\%), or managed whatever the household was able to harvest during the cropping season $(16 \%)$, to counter the impacts of climatic shocks. Migration in search of alternative livelihoods has partly been driven by unreliable rainfall and increasing incidence of dry spells and drought in the communities. Many male heads of farm households indicated that temporary migration down south for jobs is a crucial coping measure.

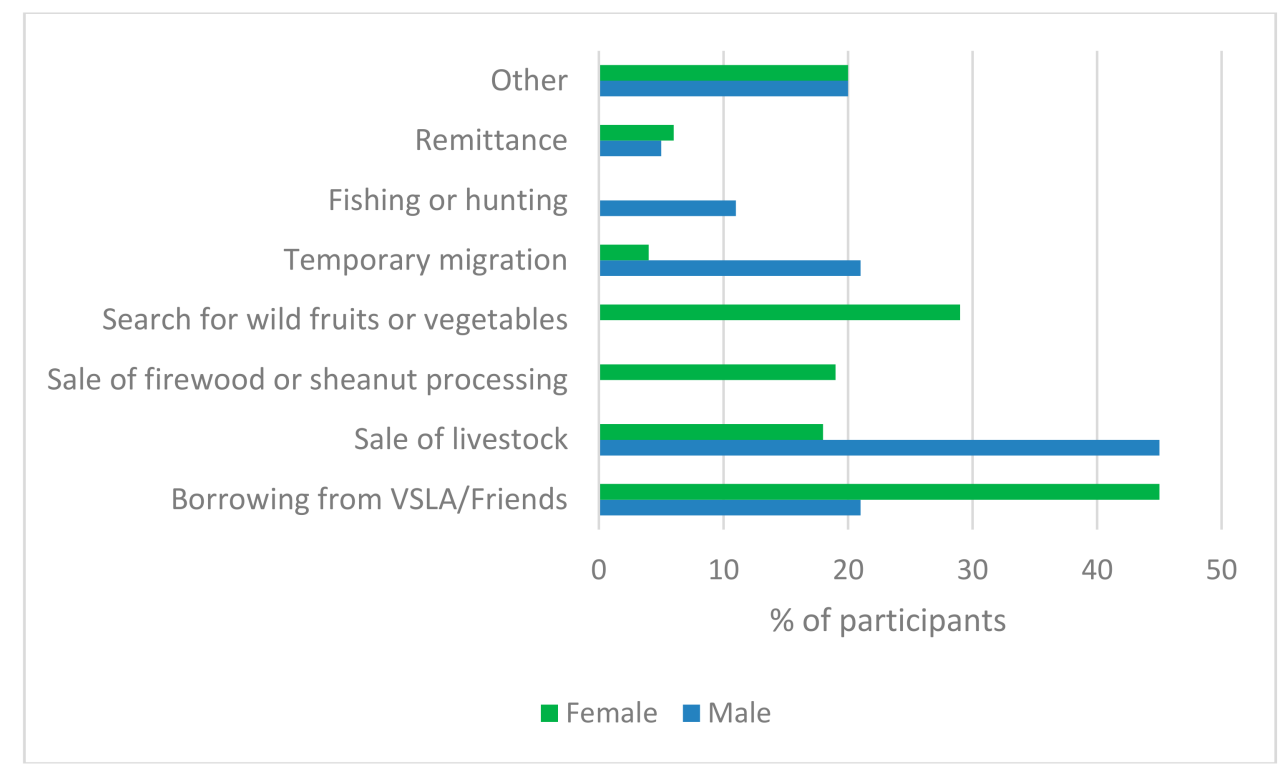

Figure 2. Measures for coping with adverse climate impacts by gender.

\subsection{Gender and Climate Change Adaptation Strategies}

All study participants reported changes in rainfall and temperature, and about $84 \%$ of study participants had implemented adaptation practices to counter the impact of the climatic shocks on their cropping activities (Table 2). Among female heads of farm households, $75 \%$ implemented adaptation strategies to improve their resilience to adverse effects of climate and climatic events. Likewise, $95 \%$ of male heads of farm households implemented some form of adaptation strategy to secure their well-being. 
Table 2. Gender differences in climate change adaptation practices among farm household heads.

\begin{tabular}{cccc}
\hline Adaptation Options & MHH (N = 56) & FHH (N = 68) & Total (N = 124) \\
\cline { 2 - 4 } & Frequency (\%) & Frequency (\%) & Frequency (\%) \\
\hline Use of improved crop varieties & $45(80)$ & $30(44)$ & $75(61)$ \\
Crop diversification & $47(84)$ & $26(38)$ & $73(59)$ \\
Soil fertility conservation practices & $49(87)$ & $35(51)$ & $84(68)$ \\
Water and soil moisture conservation practices & $49(87)$ & $36(53)$ & $85(69)$ \\
Changing planting and harvesting dates & $50(89)$ & $46(68)$ & $96(77)$ \\
Planting trees or fruit trees for shade & $43(77)$ & $25(37)$ & $68(55)$ \\
Dry season gardening & $28(50)$ & $17(25)$ & $45(36)$ \\
Use of irrigation & $22(39)$ & $11(16)$ & $33(27)$ \\
Diversify into non-farm activities & $25(45)$ & $29(43)$ & $54(43)$ \\
\hline
\end{tabular}

Note: Multiple responses recorded.

Changing crop planting and harvesting dates $(77 \%)$, water and soil moisture conservation practices $(69 \%)$, soil fertility conservation practices $(68 \%)$, use of improved crop varieties $(61 \%)$, and crop diversification (59\%) were the common adaptation strategies implemented by both male- and female-headed households. Other important but less commonly practiced adaptation strategies included planting trees or fruit trees (55\%), diversification into non-farm activities (43\%), dry season gardening $(36 \%)$, and use of irrigation ( $27 \%)$. Generally, male heads of farm households were more engaged in adaptation practices than females, except for diversification into non-farm activities.

Few female heads of farm households compared to their male counterparts engaged in adaptation strategies such as water and soil moisture conservation practices (ridging, stone or earth bunding) because they were labor-intensive. Additionally, they were unable to secure labor for these practices because of cultural norms, the location of their farms (usually low-lying, considered to be less fertile), the type of land tenure, and the types of crops they cultivated. When asked why women were constrained in accessing labor and fertile lands for their farming activities, a male key informant explains:

In our area, it is men who have access to labor because traditionally men are considered farmers. The role of the woman is to help with sowing and weeding. So, if you see a man sowing on the farm then maybe it's because the wife is sick or deceased. To see a woman sowing here is normal, but when you see a woman here farming by herself, then it means that she is widow, or the husband has migrated, making her the household head or may have chosen to farm on her own. Even if the woman had money to hire labor, the laborer will choose to work with the man because in their mind they (men) believe that if they farm for the women, the women are going to be better off (economically) than them. Men also think that women will take over their position (in the family). Also, traditionally, we believe that women are visitors in their husband's home and are supposed to help their husbands in farming. In the past women did not farm, it is recently that through sensitization programs by Non-governmental organizations (NGOs) and government officers that women have been encouraged to take up farming to support their families. However, men will give less fertile land to women because they don't want them (women) to be better off economically-KII 09 .

The preceding quote is just one example that suggests how cultural norms and perception of gender hinder adaptive abilities of female heads of farm households (and other female farmers). Though more females are taking up farming - a change from their traditional roles-because of the presence of both climatic and non-climatic stressors, they remain constrained in accessing critical resources necessary for adaptation.

\subsection{Gender and Perception of Effectiveness of Current Adaptation Practices}

The perceptions of male and female heads of farm households of the effectiveness of current adaptation practices in mitigating climate change impact are shown Table 3. The responses were 
measured on a 1 to 5 scale, with 1 indicating strategy was perceived to be not effective and 5 indicating very effective by farmers. Generally, both male and female heads of farm households perceived the adaptation measures to be effective in helping them reduce the adverse effects of variations in rainfall and temperature and extreme climatic events. The adaptation measures had an average score above 3 (somewhat effective).

Male and female heads of farm households agreed that the use of improved varieties (particularly drought-tolerant varieties) and the implementation of soil fertility conservation practices were helpful in countering the adverse effects of climate change on crop production. Other adaptation measures that were rated as being effective in helping farm households withstand climate change impacts included water and soil moisture conservation practices, use of irrigation, crop diversification, and dry season gardening.

Table 3. Gender differences in perceptions of the effectiveness of adaptation strategies.

\begin{tabular}{cccc}
\hline Adaptation Measure & $\begin{array}{c}\text { Male Heads of } \\
\text { Households }(\boldsymbol{N}=\mathbf{5 6})\end{array}$ & $\begin{array}{c}\text { Female Heads of } \\
\text { Households }(\boldsymbol{N}=\mathbf{6 8})\end{array}$ & Total (N= 124) \\
\cline { 2 - 4 } & Mean (SD) & Mean (SD) & Mean (SD) \\
\hline Improved varieties & $4.60(0.49)$ & $4.60(0.50)$ & $4.60(0.49)$ \\
Soil fertility conservation practices & $4.33(0.72)$ & $4.31(0.58)$ & $4.32(0.66)$ \\
Water and soil moisture conservation & $4.39(0.64)$ & $3.97(0.81)$ & $4.21(0.74)$ \\
Use of irrigation & $4.36(0.58)$ & $3.73(0.65)$ & $4.15(0.67)$ \\
Dry season gardening & $4.29(0.76)$ & $3.88(0.48)$ & $3.13(0.69)$ \\
Crop diversification & $3.91(0.80)$ & $3.40(0.60)$ & $3.93(0.73)$ \\
Changing planting and harvesting dates & $4.12(0.75)$ & $3.28(0.74)$ & $3.78(0.88)$ \\
Planting trees or fruit trees & $3.91(1.09)$ & $3.45(0.63)$ & $3.68(1.01)$ \\
Diversification into nonfarm activities & $3.52(1.12)$ & & $3.48(0.88)$ \\
\hline
\end{tabular}

Although considered effective in countering climate change impacts on livelihood and household well-being, staggering crop planting and harvesting dates, planting trees or fruit trees, and diversifying into nonfarm activities were rated as lower among female heads of farm households than among male heads of farm households. In the focus group discussions and key informant interviews, participants indicated that, although nonfarm activities were good alternatives for income generation, the capital-intensive nature some of the available options and lack of markets constrained their ability to adequately benefit from such activities.

\subsection{Gender and Sources and Types of External Support to Cope with Climate Change Impacts}

About $44 \%$ of the farmers indicated that they received some form of support from external sources to cope with climate change impacts. About $19 \%$ of these farmers received support from relatives, $26 \%$ from nongovernmental organizations, and $2 \%$ from government agencies. Among male heads of farm households, $27 \%$ received support from relatives. Out of these, $12 \%$ received food; $9 \%$, soft loans; $1 \%$, farm input support; and $4 \%$, money. About $27 \%$ of male heads of farm households received support from nongovernmental organizations. Of these, $9 \%$ received small ruminants; $23 \%$, improved seeds; $2 \%$, healthcare; and 5\%, others (e.g., fertilizer). A few (2\%) received irrigation pipes from government agencies as support to cope with climate change impacts. Among female heads of farm households, $13 \%$ received support from relatives. About $10 \%$ received food; $2 \%$, soft loans; and 1\%, farm inputs from relatives. Further, 25\% reported receiving support from nongovernmental organizations. Of these, $18 \%$ received small ruminants, $13 \%$ received farm inputs (seeds), and 3\% received soft loans from the NGOs.

The data indicate that the main source of external support for both types of households was NGOs. This NGO support was mostly free and aimed to help the households to diversify their income sources and to improve their resilience to the impacts of climate change. For example, vulnerable male and female heads of farm households received livestock from Canadian Feed the Future Program to build their resilience. This gesture is important for improving the resilience of female heads of 
farm households because traditionally they could not own livestock. Even if they inherited livestock from their deceased husbands, they had to relinquish ownership to their sons. But now, these female household heads can claim ownership of livestock.

Through the qualitative analysis, it was evident that government has been supporting farmers' climate change adaptation efforts through extension delivery services and improved access to subsidized farm inputs such as fertilizer, irrigation pipes, etc. In extension delivery services, efforts were made to give equal access to both male and female farmers in the study communities. However, in recent times (the past three years), extension delivery services have been low, with male farmers perceived as having more access to extension services than female farmers. A female key informant explains this:

"Access to extension delivery is very poor because we don't have enough staff numbers. The staff that we have they are just few and they cannot reach everybody ... the men who have more access to extension delivery than the women. Why because some of the women when you go, they will tell you that they are sending the child to clinic, they are going to funeral, etc. It is always a problem. But now their voices too have been heard and they are (government) employing people. And I hope that they (women) will also have that access to extension with more people being employed"-KII 02.

In accessing subsidized farm inputs provided by government, the main constraint for both male and female heads of farm households was lack of money to purchase these. A female focus group participant illustrates this:

"We don't have money to buy inputs such as fertilizer ... Sometimes, we borrow money from the savings and loans group to take care of our family and buy inputs for our farming activities"-FGD 02.

This assertion was supported by a male focus group participant, who lamented about constraints he faced in to accessing (subsidized) farm inputs:

"We don't have money to buy farm inputs and take care of our families"—FGD 01.

Even though some of the farmers received support from relatives, they indicated the need for an urgent intervention from external agencies to cope with climate change impacts and improve their food security. Specifically, participants indicated that they needed help with food, healthcare facilities, farm inputs, small ruminants, and credit. They stressed the need for the provision of grants or some form of safety net to vulnerable members of the population, which included the aged, widows, widowers, and persons with disabilities.

Further, the qualitative analysis showed that farmers were engaged in collective action toward climate change mitigation. Specifically, in all the study communities, volunteer groups monitored the activities of other community members to prevent indiscriminate tree cutting and bushfires. In two of the communities (Mettoh and Kasalgri), for example, there were bylaws to curb indiscriminate tree cutting and bush burning.

\subsection{Gender and Preference for Institutional Adaptation Support}

The preferred list of potential institutional interventions for male and female heads of farm households for improving their adaptive capacity, along with their respective rankings, is shown in Table 4. The responses were measured on a 1 to 3 scale, with 1 indicating that the adaptation option was not at all preferred and 3 indicating that the adaptation option was most preferred by farmers. Both male and female heads of households showed a preference for institutional adaptation interventions. Both male and female heads of households ranked provision of dams or dugouts and improved access to credit as the top two preferred institutional supports for adapting to changes in climate. 
Other types of adaptation support preferred among female heads of farm households included provision of postharvest processing technology and improved access to market, provision of grants or price support to farmers to cover crop and/or livestock loss to climatic stressors, increased extension education focused on equipping farmers with requisite information, and skills for building their adaptive capacity, and the provision of seasonal forecasts or a weather monitoring station.

Table 4. Gender differences in preferred institutional support for adaptation.

\begin{tabular}{|c|c|c|c|c|}
\hline \multirow{2}{*}{ Adaptation Measure } & $\begin{array}{l}\text { Male Heads of } \\
\text { Households }(N=56)\end{array}$ & \multirow{2}{*}{ Rank } & $\begin{array}{l}\text { Female Heads of } \\
\text { Households }(N=68)\end{array}$ & \multirow{2}{*}{ Rank } \\
\hline & Mean (SD) & & Mean (SD) & \\
\hline Provision of dams or dugouts & $2.93(0.26)$ & 1st & $2.84(0.37)$ & 1st \\
\hline Improved access to credit & $2.84(0.46)$ & 2nd & $2.66(0.59)$ & 2nd \\
\hline $\begin{array}{l}\text { Farmer adaptation capacity building through } \\
\text { extension education }\end{array}$ & $2.84(0.37)$ & 2nd & $2.47(0.58)$ & 4 th \\
\hline $\begin{array}{c}\text { Grants or price support to farmers to cover crop or } \\
\text { livestock loss }\end{array}$ & $2.80(0.40)$ & 5 th & $2.47(0.50)$ & 4th \\
\hline $\begin{array}{l}\text { Provision of seasonal forecast or community } \\
\text { weather monitoring station }\end{array}$ & $2.77(0.43)$ & 6th & $2.47(0.65)$ & 4th \\
\hline $\begin{array}{l}\text { Provision of postharvest processing } \\
\text { technology/Improved access to market }\end{array}$ & $2.71(0.49)$ & 7th & $2.51(0.50)$ & 3rd \\
\hline Grain bank or storage facility & $2.82(0.39)$ & 4th & $2.31(0.61)$ & 7th \\
\hline Improvement in access to and ownership of land & $2.54(0.69)$ & 8th & $2.43(0.65)$ & 8th \\
\hline
\end{tabular}

Male heads of farm households showed preference for adaptation capacity building through extension education, provision of grain banks or storage points, grants or price support to farmers to cover crop or livestock loss to climatic stressors, and the provision of seasonal forecasts or a community weather monitoring station.

\subsection{Gender and Preferred Sources of Institutional Support}

The preferred sources of institutional support for adapting to the negative impacts of climate change of male and female heads of farm households are presented in Figure 3.

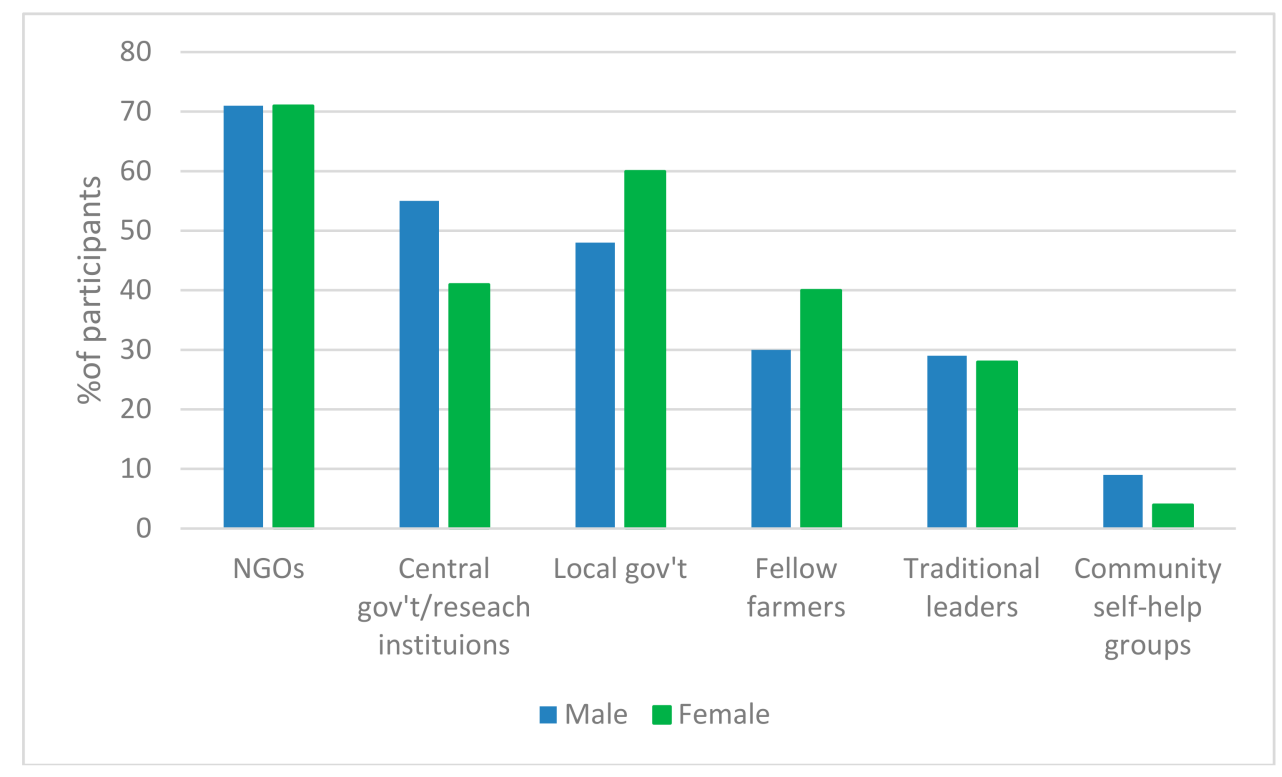

Figure 3. Farmers' preferred sources of institutional support by gender.

The top three preferred sources of institutional support for adaptation were NGOs, national government or research institutions, and local government institutions. Notably, more female than 
male heads of farm households preferred to receive support for adaptation from their local government agencies and fellow farmers. Both male and female heads of farm households showed less interest in receiving support for adaptation from community self-help groups.

In the focus group discussions and key informant interviews, it was obvious that current support for adaptation and coping measures was mostly provided by NGOs. Farmers in the three study communities mentioned that various NGOs had provided households with livestock, seeds, fertilizers, and training in alternative livelihood options to build their resilience to climate change impacts.

\section{Discussion}

The study examined the climate change coping and adaptation practices of male and female heads of farm households. It further explored the perceptions of male and female heads of farm households on the effectiveness of these adaptation practices, and assessed their preferences for institutional support for adaptation to future changes in rainfall and temperature. The results generally support results from similar studies on gender and climate change adaptation, which indicate that male and female farmers have different knowledge and agency that they draw upon in reducing their vulnerability to adverse climate change impacts [30,31]. Further, the findings show an interaction between gender and culture and social class in influencing access to and control over critical resources crucial for climate change adaptation among farm households, particularly those headed by females. Notably, the relatively low participation of females in climate change adaptation is rooted in gender relations, sociocultural norms, and power relations. Despite these existing inequalities, vulnerable male and female farmers demonstrate their resourcefulness in reducing their vulnerability to adverse climate change impacts. This latter result is consistent with the tenets of Feminist Political Ecology (FPE). The FPE framework focusing on gender as a key variable explains how the complex interactions between class, race, culture, age, ethnicity, and other forms of social categories shape access to and control over resources [38,39]. As an analytical framework, FPE sheds light on "local agency, recognizing the resourcefulness of marginalized women and men, often under significant socio-ecological constraints" [39] (p. 42). In Ghana, particularly northwestern Ghana, the result is that, though male and female farmers are willing to engage in coping and adaptation practices, they (slightly more females) are constrained by sociocultural norms and other forms of inequality.

Specifically, the results of the study demonstrate that both male and female heads of farm households have been adopting a myriad of coping measures to ensure household food security and to improve their financial status to counter the impact of climate change during abnormal cropping seasons. These results corroborate those of other studies that have reported that male and female heads of farm households adopt a range of strategies to reduce the vulnerability of their livelihoods and household well-being to climatic shocks $[30,40,41]$. The results suggest a gender dimension in the coping measures adopted by heads of farm households to reduce climate change impacts. For example, the key coping practices among female heads of farm households were borrowing from village savings and loans group and relatives, and sale of shea butter and forest resources such as firewood. Male heads of households relied instead on sale of livestock, forest resources, and temporary migration in search of jobs to meet household food and economic needs. These coping measures are commonly practiced among rural households that rely on climate-sensitive activities for their livelihoods to increase food availability and income when they experience climatic shocks on their livelihoods.

It is evident that both male and female heads of farm households depend on forest resources as coping and adaptation measures. Female heads of farm households depend on cutting and selling trees (for firewood) as a coping measure for climate change impacts; male heads of farm households primarily depend on game, sometimes setting fire to the forest during hunting. The reliance of households on sale of forest products as a coping mechanism could worsen the state of forest depletion and increase climate change impacts, and thus increase incidence of water shortages and severe droughts. Such a situation could present food security and income challenges to rural households that depend on rain-fed agriculture. Additionally, increasing depletion of the forest could affect availability 
of fodder for livestock. Alternative livelihood activities and improved farming practices can improve the economic potential of the farmers, minimize their dependence on forest resources, and control forest depletion. Even though government enactments prohibit forest fires and indiscriminate tree cutting, the enactments are poorly and unevenly enforced by mandated government agencies. The lack of enforcement can partly be attributed to lack of resources such as logistics, human and financial capital, and technical resources. Thus, provision of adequate resources by authorities and enforcement of laws could help improve the sustainability of forest resources in the arid region. Additionally, intervention programs could focus on strengthening existing community initiatives on sustainable use of forest resources through collaborations with external agencies involved in programs on sustainable use of forest resources.

Migration of male farmers in search of wage jobs to raise income to improve food security and economic status of their households could be a plausible alternative measure for climate change impacts adaptation. The absence of the male heads of households from their homes, however, could put emotional and psychological strain on their marriages or families. In addition, the migrant male farmers typically engage in nomadic livelihood activities (such as informal artisanal mining, street hawking, truck pushing) and often brave hazardous conditions to earn meager incomes, a situation that can potentially affect their health and well-being.

Climate-related shocks in rain-fed agricultural production present a significant risk to household income generation and food security. Thus, it is crucial for farm households to adjust their practices to counter the adverse impacts of climatic shocks. Consistent with findings by [26,42], farmers in northwestern Ghana adopted both farm- and nonfarm-level adaptation measures to secure their livelihoods. The top adaptation practices of farmers included changing crop planting and harvesting dates, crop diversification, soil fertility improvement practices, and use of improved crop varieties. These adaptation measures aim to improve yields and minimize crop losses, thereby improving food security status and socioeconomic well-being of the rural farm households. Relying on drought-tolerant and improved crop varieties could also ensure the economic sustainability of the farm households. Education on adaptation techniques is necessary in ensuring that the right technique is applied at the appropriate time. This education should focus on both male and female farmers, including extension service providers, and should also aim to encourage male farmers to assist female farmers in obtaining labor needed to undertake adaptation measures. Female farmers could also be trained and encouraged to adopt climate-smart push-pull adaptation strategies that are considered less labor-intensive. For example, intercropping the drought-tolerant trap plant Brachiarra spp. with drought-tolerant Desmodium intortum (green leaf desmodium) in Uganda, Kenya, Tanzania, and Ethiopia [43] improved soil fertility and minimized pest and weed infestations. Studies about the feasibility of employing similar or alternative techniques could be adopted in northeastern Ghana to improve adaptation and farming practices. However, structural conditions such as gender and cultural norms undermine the abilities of female farmers to expand their farm production by discouraging or preventing male farmers from working for female farmers or excluding female farmers from important decision-making processes. Although government agencies as well as NGOs have been working with community members (particularly females) to promote gender equality and women's development resulting in more females farming on their own, some of these norms and perceptions remain unchanged in some cases. Intensification of agricultural extension education programs that integrate topics focused on engendering behavioral and perception change, particularly among male farmers on the role of female farmers in agriculture, household food security, and well-being could help in closing the gender inequality gaps.

Understanding the perspectives of male and female farmers about the effectiveness of current climate change adaptation practices is useful for planning future adaptation interventions. Murage et al. indicated that female farmers favored less labor-intensive adaptation measures than males [37]. In this study, male farmers considered current adaptation measures as effective in mitigating climate change impacts on their livelihood activities and household well-being. The unavailability of markets or 
reduced access to markets and credit by rural households that would like to diversify into nonfarm activities has the potential to prevent households from benefitting from the opportunities associated with nonfarm activities. Building an asset base for vulnerable households could improve their resilience to climate change impacts. For example, households could be provided with small ruminants or fowls to rear for food security. In addition, policy interventions targeted at improving farm households' access to cash and input credit could be instituted to improve their livelihood activities. Compared with male heads of farm households, females gave a lower rating to planting trees or fruit trees as an effective adaptation strategy. As observed in other studies in the Upper West Region of Ghana, female farmers showed preference for adaptation measures that have benefits that could be realized in the short run because of the constraints they faced in accessing productive resources such as land and labor [13,39]. Perhaps this explains why female heads of households showed interest in adaptation measures that yield food security and income within a relatively short period. This suggests the need for incorporating gender-based assessment of climate change adaptation in planning for adaptation interventions.

Transformation of the agricultural sector from rain-fed to both rain-fed and irrigation-based could significantly ensure the adaptation of farmers to climate change impacts. Credit constraints in expanding farming activities and diversifying into nonfarm income-generating activities are also barriers to adaptation among farm households. Therefore, the transformation process could include the provision of dams and dugouts, and improved access to credit. This suggestion agrees with suggestions by [4], who indicated that provision of irrigation systems to communities in northern Ghana is important to enable farmers to adapt to increasing variability in rainfall and temperature during the crop growing season. Improving access to credit could improve farmers' capacity to engage in other income-generating activities and enable them to purchase farm inputs that are critical for adapting to the changing climate.

According to United Nations Development Program [31], male and female heads of farm households have dissimilar roles, perceptions and knowledge, needs, and control over and use of resources, which could influence their choice and preference for potential support for adapting to projected adverse climate change. Female heads of farm households preferred postharvest processing technology and improved access to markets, but male heads of farm households preferred farmer adaptation capacity building through extension education. Conventionally, females engage in processing and marketing of agricultural produce in most farm households. At present, agricultural crops are mostly sold in their raw state, often resulting in low income because of a glut on the market and low prices offered by market women to farmers. Provision of processing facilities could help female farmers to curb crop losses during storage and increase the income gained by selling processed products. On the other hand, building male farmers' adaptive capacity through extension could improve their production levels and address their concern with making the most profit from their crop and livestock production activities. These differences in preference for institutional support stress the importance of incorporating gender perspective in adaptation intervention planning to reduce or prevent maladaptation.

Goh suggests that access to land is a major barrier to climate change adaptation among smallholder farmers [14]. It was observed in this study that land access may not be a major barrier to climate change adaptation in northern Ghana. Improved access to and ownership of land for farming was a least preferred institutional support for adapting to climate change impacts among farmers in the three northwestern communities in Ghana. A similar observation was made by [44] among farmers in the Central Gonja district of northern Ghana. Thus, land rights and ownership formalization may not be a crucial concern of the farmers at the moment. Further, findings from the qualitative process suggest that lands for farming in the study area are not sold but rather allocated by the family head (usually a man) to whoever asks for it for farming. Perhaps the low preference for improvement in land access and ownership could be due to land allocation arrangements that allow household heads to plan for crop rotation and fallowing each cropping season [45]. Permanent ownership of land by other individuals in the household could disrupt those farming plans. 
It is evident that farm household needs and perspectives should be incorporated in the identification and design of adaptation practices. Adaptation intervention planning can focus on designing and identifying measures (e.g., provision of irrigation facilities) that could transform agricultural production. A transformation of the agricultural sector from rain-fed to irrigation-based could result in increased productivity and improved household food security and economic gains. With agro-processing industries, increased productivity could provide employment and reduce the rate of male migration from the communities. Further, part of the income gained from agro-processing by farmers could be invested in the formal education of their children. Such an investment could lead to increased literacy in the region as well as afford these children opportunities for higher paying jobs in the future should they choose not to engage in agriculture.

Farm households need institutional support to enable them to effectively adapt to adverse impacts of climate change. The farmers in this study preferred support from external agencies, but continuous overreliance on external support from agencies could cause the farmers to lose sight of their own abilities to develop local solutions to their problems. Therefore, it is important for institutions involved in developing adaptation interventions for communities to work with a bottom-up approach to identify locally suited strategies to prevent maladaptation. Such institutions could work with communities to identify assets such as social capital (e.g., informal networks and local associations) to create local economic opportunities for livelihood transformation and sustainable development.

\section{Conclusions}

This study assessed the climate change coping and adaptation measures adopted by male and female heads of farm households to reduce vulnerability to adverse impacts of climate change. The study further examined the perceptions of farm household heads on the effectiveness of current climate change adaptation practices and their preferences for institutional support for adapting to climate change impacts. The key observations in this study are:

- Male and female heads of farm households mainly engage in borrowing from village savings and loans groups, sale of forest products, sale of livestock, and temporary migration, as coping measures to reduce the impact of climatic shocks on their livelihood activities.

- More male heads than female heads of farm households engage in climate change adaptation practices.

- Both male and female heads of farm households perceived current adaptation practices as effective in reducing the effects of adverse climate change impacts on their livelihoods and household well-being.

- The most preferred types of potential institutional adaptation support for both male and female heads of households are dams, dugouts, and improved access to credit.

- NGOs and government agencies were the most preferred sources of institutional support for climate change adaptation.

The findings in this study have implications for climate change mitigation and adaptation planning. Engagement of agricultural extension agents, forestry officers, and community members in sustainable use of forest resources and reforestation could enhance food security and income generation among households. Further, less labor-intensive adaptation practices could improve the resilience of farmers to adapt to climate change impacts.

The provision of dams and dugouts and improved access to credit could transform agricultural production and reduce farm households' vulnerability to the adverse impacts of climate change. Stakeholders can engage financial institutions to help local savings organizations to improve access to credit and ensure farmers' financial accountability to lenders. Stakeholder interventions could be directed at improving farm households' access to both tangible and intangible asset holdings-including small ruminants, information on how to access credit, and links to markets-to improve their adaptive capacity. 
These efforts, however, may not yield the expected results because of gender norms and cultural perceptions. Education of all stakeholders can undo these norms and perceptions and improve the adaptive capacity of farmers, particularly female farmers. An inclusive, bottom-up approach between communities and other stakeholders to identify and design future climate change adaptation measures suited to local needs could lead to livelihood transformation, reduce maladaptation, and promote socioeconomic sustainability.

Author Contributions: E.A. identified the research question, designed and carried out data collection and analysis, and interpretation of the results. She also prepared the original draft of the article. M.S., L.S.O. and A.A. contributed significantly to reviewing and editing the draft, and provided guidance and supervision during the conduct of the study.

Funding: This research received no external funding.

Acknowledgments: We appreciate financial support from the Department of Community Sustainability, Michigan State University, USA, in the conduct of this research. Gladys Ama Assan, GIS expert and database officer with Environment Division of SGS Ghana Limited, helped with the GIS map of the study area. Special thanks to the farmers and community leaders who participated in this study. We appreciate the thoughtful suggestions and comments from two anonymous reviewers which helped in improving the quality of the paper.

Conflicts of Interest: The authors declare no conflict of interest.

\section{References}

1. Jalloh, A.; Nelson, G.C.; Thomas, T.S.; Zougmore, R.; Roy-Macauley, H. West African Agriculture and Climate Change: A Comprehensive Analysis; International Food Policy Research Institute: Washington, DC, USA, 2013.

2. Nelson, G.C.; Rosegrant, M.W.; Palazzo, A.; Gray, I.; Ingersoll, C.; Robertson, R.; Tokgoz, S.; Zhu, T.; Sulser, T.B.; Ringler, C.; et al. Food Security, Farming, and Climate Change to 2050: Scenarios, Results, Policy Options; International Food Policy Research Institute: Washington, DC, USA, 2010.

3. Food and Agriculture Organization. Socio-Economic Context and Role of Agriculture. Ghana Country Fact Sheet on Food and Agriculture Policy Trends; Agriculture Policy Decision Analysis (FAPDA) of FAO; FAO: Rome, Italy, 2015.

4. Stanturf, J.A.; Warren, M.L.J; Charnley, S.; Polasky, S.C.; Goodrick, S.L.; Armah, F.; Nyako, Y.A. Ghana Climate Change Vulnerability and Adaptation Assessment. 2011. Available online: http:/ /www.encapafrica. org/documents/biofor/ClimateChangeAssessment_Ghana_FINAL.pdf (accessed on 23 June 2018).

5. Ndamani, F.; Watanabe, T. Farmers' perceptions about adaptation practices to climate change and barriers to adaptation: A micro-level study in Ghana. Water 2015, 7, 4593-4604. [CrossRef]

6. Climate Change and Agriculture: A Review of Impacts and Adaptations. Available online: https:// openknowledge.worldbank.org/bitstream/handle/10986/16616/787390WP0Clima0ure0377348B00PUB LIC0.pdf? sequence $=1 \&$ is Allowed $=y$ (accessed on 23 June 2018).

7. Stutley, C. Innovative Insurance Products for the Adaptation to Climate Change Project Ghana (IIPACC): Crop Insurance Feasibility Study 2010. Available online: http://seguros.riesgoycambioclimatico.org/ dinteres_e.php (accessed on 23 June 2018).

8. Bawayelaazaa Nyuor, A.; Donkor, E.; Aidoo, R.; Saaka Buah, S.; Naab, J.; Nutsugah, S.; Bayala, J.; Zougmore, R. Economic Impacts of Climate Change on Cereal Production: Implications for Sustainable Agriculture in Northern Ghana. Sustainability 2016, 8, 724. Available online: http:/ /www.mdpi.com/20711050/8/8/724 (accessed on 23 June 2018). [CrossRef]

9. Antwi-Agyei, P.; Stringer, A.J.; Dougill, A.J.; Stringer, L.C.; Dougill, A.J. Livelihood adaptations to climate variability: Insights from farming households in Ghana. Reg. Environ. Chang. 2014, 14, 1615-1626. [CrossRef]

10. Bawakyillenuo, S.; Yaro, J.A.; Teye, J. Exploring the autonomous adaptation strategies to climate change and climate variability in selected villages in the rural northern savannah zone of Ghana. Local Environ. 2016, 21, 361-382. [CrossRef]

11. Yaro, J.A. The perception of and adaptation to climate variability/change in Ghana by small-scale and commercial farmers. Reg. Environ. Chang. 2013, 13, 1259-1272. [CrossRef]

12. Deressa, T.; Hassan, R.; Ringler, C. Perception of and adaptation to climate change by farmers in the Nile basin of Ethiopia. J. Agric. Sci. 2011, 149, 23-31. Available online: http:/ /www.journals.cambridge.org/ abstract_S0021859610000687 (accessed on 23 June 2018). [CrossRef] 
13. Jost, C.; Kyazze, F.; Naab, J.; Neelormi, S.; Kinyangi, J.; Zougmore, R.; Aggarwal, P.K.; Bhatta, G.D.; Chaudhury, M.; Tapio-Bistrom, M.L.; et al. Understanding gender dimensions of agriculture and climate change in smallholder farming communities. Clim. Dev. 2015, 5529, 1-12. Available online: http:/ /www. scopus.com/inward/record.url?eid=2-s2.0-84936970692\&partnerID=tZOtx3y1 (accessed on 23 June 2018). [CrossRef]

14. Goh, A. A Literature Review of the Gender-Differentiated Impacts of Climate Change on Women's and Men's Assets and Well-Being in Developing Countries; International Food Policy Research Institute (IFPRI): Washington, DC, USA, 2012.

15. Codjoe, S.N.A.; Atidoh, L.K.; Burkett, V. Gender and occupational perspectives on adaptation to climate extremes in the Afram Plains of Ghana. Clim. Chang. 2012, 110, 431-454. [CrossRef]

16. Alston, M. Gender mainstreaming and climate change. Womens Stud. Int. Forum 2014, 47, 287-294. [CrossRef]

17. Climate Change and Gender: What Role for Agricultural Research among Smallholder Farmers in Africa? Available online: http:/ / ciat-library.ciat.cgiar.org:8080/jspui/bitstream/123456789/5358/1/WD222_WEB_ FINAL.pdf (accessed on 23 June 2018).

18. Antwi-Agyei, P.; Dougill, A.J.; Fraser, E.D.G.; Stringer, L.C. Characterising the nature of household vulnerability to climate variability: Empirical evidence from two regions of Ghana. Environ. Dev. Sustain. 2013, 15, 903-926. [CrossRef]

19. Ahmed, A.; Lawson, E.T.; Mensah, A.; Gordon, C.; Padgham, J. Adaptation to climate change or non-climatic stressors in semi-arid regions? Evidence of gender differentiation in three agrarian districts of Ghana. Environ. Dev. 2016, 20, 45-58. [CrossRef]

20. Kandlikar, M.; Risbey, J. An Editorial Comment. Clim. Chang. 2000, 45, 529-539. [CrossRef]

21. Lambrou, Y.; Nelson, S. Farmers in a Changing Climate: Does Gender Matter? Food and Agriculture Organization of the United Nations: Rome, Italy, 2010.

22. Davies, S. Corded Greater Importance Than in the Past. IDS Bull. 1993, 24, 60-73. [CrossRef]

23. Intergovernment Panel on Climate Change. IPCC 2007: Impacts, Adaptation and Vulnerability: Contribution of Working Group II to the 4th Assessment Report of the Intergovernmental Panel; IPCC: Geneva, Switzerland, 2007.

24. Downing, T.E.; Ringius, L.; Hulme, M.; Waughray, D. Adapting to climate change in Africa. Mitig. Adapt. Strateg. Glob. Chang. 1997, 2, 19-44. [CrossRef]

25. Smit, B.; Pilifosova, O.; Burton, I.; Challenger, B.; Huq, S.; Klein, R.J.T.; Yohe, G.; Adger, N.; Downing, T.; Harvey, E.; et al. Adaptation to Climate Change in the Context of Sustainable Development and Equity. In Climate Change 2001 Work Group II Impacts, Adapt Vulnerability; IPCC: Geneva, Switzerland, 2001; pp. 880-912.

26. Nhemachena, C.; Hassan, R.M. Micro-Level Analysis of Farmers' Adaptation to Climate Change in Southern Africa; IFPRI Discussion Paper, 00714; International Food Policy Research Institute: Washington, DC, USA, 2007.

27. Orindi, V.A.; Eriksen, S. Mainstreaming Adaptation to Climate Change in the Development Process in Uganda; Ecopolicy Series 15; African Centre for Technology Studies (ACTS): Nairobi, Kenya, 2005.

28. Hisali, E.; Birungi, P.; Buyinza, F. Adaptation to climate change in Uganda: Evidence from micro level data. Glob. Environ. Chang. 2011, 21, 1245-1261. [CrossRef]

29. Fosu-Mensah, B.Y.; Vlek, P.L.G.; MacCarthy, D.S. Farmers' perception and adaptation to climate change: A case study of Sekyedumase district in Ghana. Environ. Dev. Sustain. 2012, 14, 495-505. [CrossRef]

30. Diiro, G.; Petri, M.; Zemadim, B.; Sinare, B.; Dicko, M.; Traore, D. Gendered Analysis of Stakeholder Perceptions of Climate Change, and the Barriers to Its Adaptation in Mopti Region in Mali. Telangana, India, 2016. Available online: http:/ / oar.icrisat.org/9512/1/TextGenderAnalysis.pdf (accessed on 23 June 2018).

31. United Nations Development Programme (UNDP). Gender, Climate Change and Community-Based Adaptation. UNDP: New York, 2010. Available online: http://www.undp.org/content/dam/aplaws/ publication/en/publications / environment-energy / www-ee-library / climate-change/gender-climatechange-and-community-based-adaptation-guidebook-/Gender\%20Climate $\% 20$ Change $\% 20$ and $\%$ 20Community\%20Based\%20Adaptation\%20 (accessed on 23 June 2018). 
32. Tibesigwa, B.; Visser, M.; Hunter, L.; Collinson, M.; Twine, W. Environment for Development Gender Differences in Climate Change Risk, Food Security, and Adaptation. A Study of Rural Households' Reliance on Agriculture and Natural Resources to Sustain Livelihoods; Economic Research Southern Africa (ERSA): Cape Town, South Africa, 2015; pp. 1-33.

33. Ghana Statistical Service. 2010 Population and Housing Census_Lawra District. Accra, Ghana, 2014. Available online: http:/ / www.statsghana.gov.gh/docfiles/2010_District_Report/UpperWest/LAWRA.pdf (accessed on 23 June 2018).

34. Babbie, E. Research Design. In The Practice of Social Research, 12th ed.; Cengage Learning: Belmont, CA, USA, 2010; pp. 90-123.

35. Charmaz, K. Constructing Grounded Theory: A Practical Guide through Qualitative Analysis; Sage: Newcastle upon Tyne, UK, 2006; Volume 10, p. 208.

36. Beotto, H.; Mckinnon, J. Rural women and climate change: A gender-inclusive perspective. Aust. Soc. Work. 2013, 66, 234-247. [CrossRef]

37. Yeboah, F.K.; Kaplowitz, M.D.; Kerr, J.M.; Lupi, F.; Thorp, L.G. Sociocultural and institutional contexts of social cash transfer programs: Lessons from stakeholders' attitudes and experiences in Ghana. Glob. Soc. Policy 2016, 16, 287-308. [CrossRef]

38. Rocheleau, D.; Thomas-Slayter, B.; Wangari, E. Gender and Environment: A Feminist Political Ecology Perspective. In Feminist Political Ecology: Global Issues and Local Experiences; Rocheleau, D., Thomas-Slayter, B., Wangari, E., Eds.; Routeledge: New York, NY, USA, 1996; pp. 3-23.

39. Nyantakyi-Frimpong, H.; Bezner-Kerr, R. The relative importance of climate change in the context of multiple stressors in semi-arid Ghana. Glob. Environ. Chang. 2015, 32, 40-56. [CrossRef]

40. Jin, J.; Wang, X.; Gao, Y. Gender differences in farmers' responses to climate change adaptation in Yongqiao District, China. Sci. Total Environ. 2015, 538, 942-948. [CrossRef] [PubMed]

41. Wrigley-Asante, C.; Owusu, K.; Egyir, I.S.; Owiyo, T.M. Gender dimensions of climate change adaptation practices: The experiences of smallholder crop farmers in the transition zone of Ghana. Afr. Geogr. Rev. 2017, 6812, 1-14. [CrossRef]

42. Tambo, J.A.; Abdoulaye, T. Smallholder farmers' perceptions of and adaptations to climate change in the Nigerian savanna. Reg. Environ. Chang. 2013, 13, 375-388. [CrossRef]

43. Murage, A.W.; Pittchar, J.O.; Midega, C.A.O.; Onyango, C.O.; Khan, Z.R. Gender specific perceptions and adoption of the climate-smart push-pull technology in eastern Africa. Crop Prot. 2015, 76, 83-91. Available online: http:/ / www.sciencedirect.com/science/article/pii/S0261219415300545 (accessed on 23 June 2018). [CrossRef]

44. Antwi-Agyei, P.; Quinn, C.H.; Adiku, S.G.K.; Codjoe, S.N.A.; Dougill, A.J.; Lamboll, R.; Dovie, D.B.K. Perceived stressors of climate vulnerability across scales in the Savannah zone of Ghana: A participatory approach. Reg. Environ. Chang. 2017, 17, 213-227. [CrossRef]

45. Naylor, R. Women farmers and economic change in Northern Ghana. Gend. Dev. 1999, 7, 39-48. [CrossRef] [PubMed]

(C) 2018 by the authors. Licensee MDPI, Basel, Switzerland. This article is an open access article distributed under the terms and conditions of the Creative Commons Attribution (CC BY) license (http:// creativecommons.org/licenses/by/4.0/). 